\title{
Exploring firm-community level trust in rural Africa through the lens of oil companies' Corporate Social Responsibilities.
}

\begin{abstract}
Purpose: The paper explores firm-community level trust in rural Africa through the lens of oil companies' Corporate Social Responsibilities (CSR).

Methods: This paper is grounded on a case study of local communities and other stakeholders in a Nigerian community exploring the underlying triggers of distrust and trust between oil companies and rural communities through the lens of CSR.
\end{abstract}

Finding: This exploratory study found the presence of high-level firm-community expectation differentials, pointing to considerable mistrust between local communities and oil companies' CSR initiatives.

Implication: The local communities tend to feel oil companies attempt to secure social license to operate (SLO) by engaging in CSR initiatives but not to genuinely improve their welfare. There is therefore a superficial effort or incentive for oil companies to engage in CSR initiatives in rural Africa.

Originality: The paper highlights the notion that building a community-driven CSR requires a partnership in which local communities share legitimacy with government agencies and oil companies in influencing CSR initiatives. This represents the most effective way towards enhancing firm-community level trust and social legitimacy in rural Africa.

Keywords: Trust, Corporate Social Responsibility, Oil companies, Rural Africa, Community level

\subsection{Introduction}

The corporate social responsibility (CSR) field is one that is well established within the bounds of existing research (Fulmer \& Dirks, 2018; Lumineau \& Schilke, 2018). The issue surrounding CSR and firm-community mistrust, or expectation differentials is not new to the literature, however, our paper addresses an important CSR research niche which strongly supports the development of an appropriate framework to tackle firm-community expectation differentials. Though our findings aligned solidly within the bounds of existing research, our paper underscores the usefulness of building CSR partnership in which local communities share legitimacy with government agencies and oil companies in influencing CSR initiatives in rural Africa. This represents the most useful approach towards addressing firm-community mistrust, which in turn increases corporate firms' social legitimacy in rural Africa. Conceptually, this paper provides a theoretical basis and guidance for firms' operating in rural Africa to advance shared legitimacy in CSR initiatives. Importantly, firm-community level trust remains an evolving CSR issue that merits research attention with the potential to contributing to the broader CSR literature, especially in relation to developing countries, in which context Africa is largely under-researched. When the underpinning triggers of mistrust and trust between oil 
companies and communities are explored in detail through the lens of CSR, an appropriate framework can be developed to address differentials between the expectations of firms and communities. Implicitly or explicitly, trust or mistrust exists at various theoretical levels individual, group and organisational (Korsgaard et al., 2018; Lumineau \& Schilke, 2018).

Fundamentally, the notion of trust or mistrust remains multifaceted in nature, hence the need for examination at different levels, both organisational and individual (Fulmer \& Dirks, 2018). Korsgaard et al. (2018, p.143) argue 'that trust is dynamic in nature which is characterized by a multilevel construct that starts with a framework of intra-individual changes but incorporates a multilevel perspective to explore the influence of higher-order factors'. While the literature has examined the different levels of trust, much of the focus has been on trust at individual, group, and intra-organisational levels (Lumineau \& Schilke, 2018; Fulmer \& Dirks, 2018), with limited research focussed on firm-community level trust through the lens of CSR, particularly in rural Africa. This paper examines firm-community level trust through the lens of oil companies' CSR initiatives in rural Nigeria. Undeniably, the academic community acknowledges the complex and controversial nature of CSR research involving firms operating in the extractive sector (Du \& Viera Jr., 2012), particularly in developing economies across the Sub-Saharan African region. These complexities raise some concerns and support broad-based stakeholder consultations and involvement in exploring firm-community level trust through the lens of oil companies' CSR. One line of argument raised in the wider CSR literature concerns how firms can enrich community-level trust via CSR initiatives (Herrera-Racionero, LizcanoFernández \& Miret-Pastor, 2015).

The emergence of CSR has gained importance in both developed and less developed economies as organisations must demonstrate good citizenship behaviour in addressing social problems (Haalboom, 2012; Liao et al., 2017; Onyishi et al., 2020). Primarily, there is a consensus that oil and gas exploration activities impose considerable social and environmental impacts on local communities and by extension oil companies explicitly face social and environmental responsibilities (Liao et al., 2017). The social and environmental obligations of oil companies make CSR initiatives and maintaining firm-community level trust important and significant (Xiao et al., 2018; Thieme, 2015). In recent times, several societal actors at varied levels have raised concerns about CSR activities of multinational enterprises (MNEs) in local communities in Nigeria, yet limited research has attempted to explore the extent and nature of firmcommunity expectation differentials in the extractive sector. Exploring firm-community expectation differentials may provide possible alternatives for the management of CSR that can simplify firm-community relations (Auty, 2012; Ngoasong, 2014; Thieme, 2015). Enriching firm-community level trust may potentially feed into a firm's national and global social legitimacy (Ablo, 2018; Thieme, 2015). Arguably, a great part of corporate organisations' CSR initiatives has been based on the expectancy approach, which has been demonstrated to be ineffective too many times in natural resource-endowed countries in subSaharan Africa (Ngoasong, 2014; Ayentimi et al., 2016). The expectancy approach to CSR is built on the underlying assumption that firms are expected to voluntarily undertake some initiatives in support of community sustainability (Ayentimi et al., 2016; Auty, 2012; Dongkun $\& \mathrm{Na}, 2010$ ). Rather, corporate organisations are building on their fundamental principles of allocating resources for profit maximisation, widely supported by free market economists. This paper, based on legitimacy and stakeholder theories, extends the debate about differentials in firms' and communities' expectations with a potential contribution in the niche area of MNEs' engagement with local communities in developing markets from the perspective of CSR. 


\subsection{CSR in Eastern Obolo: the lens of legitimacy and stakeholder theory}

The extractive sector, particularly oil and gas, is a well-established sector in Nigeria and has remained one of the main drivers of economic growth and development (Ako, 2009; Nzeh et al., 2017). However, there are several unattractive events and developments in recent times including the intense political and security crisis triggered by Boko Haram, the fight against corruption, and low oil prices that are creating some enduring economic concerns for Africa's most populated and oil-endowed country. Eastern Obolo is a major oil-producing local council in Nigeria located within the creeks of the Niger Delta region. Historically, crude oil was discovered in Eastern Obolo in the late 1950s and by 1959, Shell British Petroleum (SBP), now Shell Petroleum Development Company (SPDC), had begun operations in the area. In addition to SPDC, ExxonMobil Producing Nigeria limited, Total E\&P, Chevron, Texaco and Amni International Petroleum Development Company are among well-known MNEs operating in Nigeria. Despite being the host to these oil companies, the area has experienced under development involving a deprivation of the benefits of the resources extracted from its land. These oil firms are generally perceived not to recognise Eastern Obolo as a priority area deserving special attention (Oke, 2006), yet the area remains the powerhouse of oil and gas exploration in Nigeria. It is important to acknowledge that some companies have made efforts to support some of the villages in the council, but the efforts have largely been perceived by these communities to be unimpressive (Ite, 2005) coupled with the persistent poor infrastructural development and lack of social amenities. Interestingly, prior literature highlights government failure and the perceived assumption that oil companies through their CSR have contributed not enough to community development (Ite, 2005, 2007). In a position paper to the Nigerian Petroleum Development Company (NPDC), the people lamented by arguing that:

...Our experiences and engagement with SPDC and its agents for the last 20 years left much to be desired despite the widely publicized, orchestrated and avowed stand of the oil and gas giant (Shell) as a good corporate citizen. Her activities in Iko Town depicted deliberate oppression, denigration, derision, marginalization, dehumanization and despicable condition reminiscent of the colonial era ( $31^{\text {st }}$ May 2017 communique issued by community members).

While we acknowledge government failure, some prior studies have documented some evidence of different CSR initiatives MNEs have promoted in Niger Delta communities ranging from company-led initiatives to community-led initiatives (Onyishi et al., 2020; Egbon et al., 2018). For instance, ExxonMobil has supported communities with the construction of schools and health centres and provided water for some communities (Oke, 2006). Total E\&P has also, through the Eastern Obolo Community Development Foundation (now defunct), built some limited infrastructure for some selected communities. Amni International Petroleum Development Company has also supported Eastern Obolo through offering employment and scholarships to students, providing training for some indigenes to acquire various skills, and school infrastructure in some villages in the council. Despite such documented level of support, these communities in Eastern Obolo seem "unimpressed" with the level of support provided by oil companies operating in the area.

Within this context of firm-community expectation differentials, trust is a vital element and as such, corporate entities need to maintain trust with communities as they do not exist in isolation and require both material and human resources from the society (Susith \& Stewart, 2014). Legitimacy theory is grounded on the assumption of a social contract between society and 
corporate organisations. Legitimacy theory argues 'that business operates in society via a social contract where it agrees to perform various socially desired actions in return for approval of its objectives, other rewards and its ultimate survival' (Guthrie \& Parker, 1989, p.344). In this regard, corporations may justify their continued existence by legitimising their actions through CSR initiatives to attain a convergence between their in-built social values in their operations and those of societal norms and expectations (Hunoldt et al., 2018; Bond et al., 2018). Indeed, legitimacy theory provides the lens to understand corporations' incentive for investing in CSR initiatives and has widely been well established in the CSR literature (Duff, 2017; Susith \& Stewart, 2014). The emphasis in the notion of a social contract is on whether a corporation operates in line with societal expectations or within the norms and values of the society (Susith \& Stewart, 2014). According to Susith and Stewart (2014), the social contract between corporate entities and the society could be somewhat explicit and somewhat implicit, where the former may be underpinned by some legal or regulatory requirements and the latter represents societal expectations (Du \& Viera Jr., 2012; Haalboom, 2012; Susith \& Stewart, 2014). This resonates with the conceptualisation of institutional legitimacy into regulatory, normative and cultural categories (Scott, 2001), which we consider similar to legitimacy theory (Bond et al., 2018). While the regulatory archetype of institutional legitimacy is underpinned by legal sanctions, the normative and cultural dimensions incorporate moral governance and expectations for community participation, accountability and transparency (Hummel \& Schlick, 2016; Bond et al., 2018). The ability of a corporation to sustain both dimensions of the social contract could help in gaining both legal and social legitimacy. For example, the environmental and social cost such as the disruption of communities' livelihood and pollution caused by the operations of oil and gas companies are absorbed by communities without any associated cost to the corporation. Accordingly, the communities would expect some accompanying benefits to compensate for the cost in order to allow the corporation continued existence (Susith \& Stewart, 2014). Over the last few years and within the accounting discipline, many advocates have drawn on legitimacy theory to argue that disclosure of CSR information represents an important element of the social responsibility of corporations (Hummel \& Schlick, 2016; Duff, 2017). It has been argued that corporations' legitimacy may be threatened when they fail to meet CSR information disclosure requirements, even when societal expectations are met (Lanis \& Richardson, 2012).

Categorically, legitimacy theory supports the notion of corporations fulfilling societal expectations not simply as a legal requirement, but also as a social obligation and a sign of corporate citizenship behaviour (Bond et al., 2018; Du \& Viera Jr., 2012). Similarly, stakeholder theory argues that corporations have a moral responsibility to satisfy the interest of their constituents (Barney \& Harrison, 2018; Yeun et al., 2017). Stakeholder theory is centred on a shared responsibility, where the value created by corporations should be shared by a variety of stakeholders, particularly stakeholders with interests in the operations of the corporation (Theodoulidis et al., 2017). Stakeholder theory has generally been recognised and examined from a managerial perspective as the responsibility is on the manager to ensure that a spill-over of the value created is extended to include the wider society (Farmaki \& Farmakis, 2018; Theodoulidis et al., 2017). Within the CSR literature, it has been argued that stakeholder management provides the space for corporate organisations to exhibit responsiveness in their corporate responsibility activities to the wider society (Jamali \& Karam, 2018; Farmaki \& Farmakis, 2018; Liu et al., 2015; Sadler \& Lloyd, 2009). Stakeholder theory provides the lens to understand diverse stakeholder interests and how corporate organisations develop strategies to create some convergence between the different stakeholder interests (Dal Maso et al., 2018; Tullberg, 2013). Despite the extended list of a firm's stakeholders, Farmaki and Farmakis (2018) draw on the instrumental stakeholder theory to argue that firms must give priority to 
stakeholders with the potential to impact organisational success owing to constraints of limited resources.

The prioritisation and categorisation of stakeholders' interests can be underpinned by power, urgency and legitimacy (Tullberg, 2013; Dal Maso et al., 2018). While power denotes the level of stakeholder influence, legitimacy is strengthened by legal and contractual agreements and urgency represents the need for responsiveness (Farmaki \& Farmakis, 2018; Mitchell et al., 1997). The attributes of power, urgency and legitimacy provide an important framework for the prioritisation of stakeholders' interests and building stakeholder relationships (Lafreniere et al., 2013; Dal Maso et al., 2018). Studies through the lens of stakeholder theory recognise the existence of gaps between the interest of the organisation and that of its stakeholders (Dal Maso et al., 2018; Farmaki \& Farmakis, 2018; Tullberg, 2013). The inability of organisations to recognise the interest of stakeholders may result in resistance and dissatisfaction (de Gooyert et al., 2017). Importantly, stakeholder engagement is considered an important avenue to addressing gaps between interests of the organisation and its stakeholders and support in building reciprocally beneficial relationships between organisations and their stakeholders (de Gooyert et al., 2017; Lafreniere et al., 2013). The extent of stakeholder engagement is underpinned by organisational commitment and firm-community trust. Arguing through the perspectives of stakeholder theory and legitimacy theory, host communities are increasingly demanding that corporations fulfill their societal expectations not simply as a legal requirement, but also as a social obligation and a sign of corporate citizenship behaviour. Therefore, we argue that the extent to which companies act to address CSR issues may potentially determine how they contribute to fulfilling the social contract and building up their social legitimacy which is underpinned by trust and the intersection of the expectations of firms with those of communities.

\subsection{Methods}

\subsection{Case study description}

The strength of exploratory qualitative research is characteristically seen as theory generation and explanation rather than testing a theory (Reinecke et al., 2016, p. xiii). Broadly, the field of CSR research is well established, however, the niche focus of the research that is the geographical location under examination warrants an exploratory qualitative research design. This is principally valuable for exploratory qualitative research involving up-and-coming enquiries in under researched contexts (with particular reference to Eastern Obolo), where little or no prior literature exists to be able to develop or formulate testable hypotheses (Reinecke et al., 2016). Importantly, given that exploratory qualitative study typically proceeds inductively from data collection to supporting theory building, it can potentially discover areas and themes where a quantitative study approach would struggle to find sufficient evidence or data (Reinecke et al., 2016). This paper is grounded on a case study of local communities and other stakeholders in a Nigerian community to exemplify the extent and nature of firm-community expectation differentials as well as the aspects of distrust or trust that exist between oil companies and local communities. The case study community members depend on fishing and subsistence farming for their livelihood. The communities are located in Eastern Obolo, Akwa Ibom State, Nigeria. Although the main basis of the local economy in the state is oil and gas, agriculture, particularly fishing, remains the major source of economic livelihood for the majority of the population. The fisheries industry in Nigeria in general has not been welldeveloped and institutionalized as its contribution to Gross Domestic Product (GDP) remains low and by extension, the subsistence nature of fishing in the community is entrenched. The 
rationale for this study location was driven by its being an exemplary case of a community impacted by the activities of oil and gas exploration. The struggle between local communities and oil and gas companies in Eastern Obolo provides a paradigmatic case to explore the extent and nature of firm-community expectation differential as well as the aspects of distrust or trust that exist between oil companies and local communities.

\subsection{Key informants}

The selection criterion of key informants for the study was to address the complexity and controversial nature of CSR research involving firms operating in the extractive sector. These controversies raise some concerns and support broad-based stakeholder consultations and involvement in exploring firm-community level trust. On that basis, three key considerations were observed. The first was that informants representing local government departments and agencies were those actively involved with oil companies and/or communities' interactions. Second, informants working in oil companies were at a management level where were able to exert some kind of decision-making authority. Third, key informants from the community level were either actively involved with companies and/or communities' interactions or were casualties of oil companies' operations (fishermen). Of the 36 participants, 4 were companies' management representatives, 10 were government departments' and agencies' representatives, and 22 were representatives of community groups and individual fishermen. Among the community level informants was Eastern Obolo Community Relations Committee, which is the committee set up by the local government in conjunction with the traditional rulers' council to interface with oil companies. Others were paramount rulers, youth representatives and female leaders.

\subsection{Data collection procedures}

This study draws on semi-structured interviews with locals, as well as informal conversations with diverse key stakeholders at the local government and community levels. The face-to-face semi-structured interviews were conducted from $19^{\text {th }}$ February 2018 to $28^{\text {th }}$ July 2018 . We developed two different interview guides prior to the data collection due to the diverse category of participants. For example, companies' management representatives had a slightly different interview guide from government representatives while for the fishermen, the interviews were generally driven by informal conversations. Participants were asked a series of questions in relation to CSR activities undertaken by oil companies in their communities, their level or nature of involvement in these CSR activities, their assessment of the impact of these CSR initiatives, etc. Furthermore, in order to specifically explore the extent of firm-community level trust, we asked participants to evaluate and describe their level of satisfaction with CSR activities undertaken by oil companies. Participants were also asked to evaluate the nature of their relationship with oil companies operating in their localities. During the interview process, explicit attention was paid to aspects of distrust or trust that exist between oil companies and local communities. While the interviews were conducted in Andoni language with fishermen, English was the mode of communication with participants from oil companies and other key stakeholders from the local government departments and agencies. All the interviews were audio-recorded and transcribed. The interviews conducted in Andoni language were translated into English. Each interview lasted for 45 to 60 minutes. Each participant's consent was sought before the interviews were granted. Overall, 36 interviews were conducted with locals and key stakeholders. Due to the controversial nature of the topic of inquiry, varied data sources were used to confirm the emerging findings for the purposes of data triangulation. 
The data was coded using Nvivo software, which is a standard software for managing qualitative data. We employed the critical-discourse analysis (Graham, 2003) followed by Herrera-Racionero et al. (2015). Critical discourse analysis is an approach that permits 'a vigorous assessment of what is meant when language is used to describe and explain an event or situation' (Fairclough, 2005). Herrera-Racionero et al. (2015, p.131) advocate that 'the elements of the research will make sense through the interpretation of the speeches, as these interviews take place within a frame of comprehension, communication and interaction, which is part of wider socio-cultural structures and processes'. The evidence presented in this paper is based on key participants' views about the extent of firm-community level trust between local communities and oil companies. In order to deepen our analysis, issues that were not specifically sought for during the interview but appeared to have emerged repeatedly from several participants were considered (Herrera-Racionero et al., 2015).

\subsection{Difficulties of the research and Closing-the-Loop}

It is important to highlight that both the academic community and civil society organisations acknowledge the complex and controversial nature of CSR research involving firms operating in the extractive sectors (Du \& Viera Jr., 2012), particularly in developing economies across the Sub-Saharan region. The historical trend of contention between local communities and oil companies in Nigeria further creates difficulties in exploring the extent and nature of firmcommunity level trust between oil companies and local communities. Further, we acknowledge the difficulties translating typical fishermen's forms of expression in a local language into English. In this regard and in order to maintain a rigorous analysis of informants' views, we tried as much as possible to keep with their literal expressions.

\subsection{Results}

In this section, we include the analysis of the CSR of oil companies in a Nigerian local government area. A majority of the participants seemed to believe that the presence of the oil companies in Eastern Obolo had not improved the quality of life in the area. They tended to feel that oil and gas companies attempt to secure SLO by engaging in CSR initiatives but not to genuinely improve their welfare. Social license is embedded in the opinions, perceptions and beliefs held by local key stakeholders and communities about the operation of a business enterprise or a project. The SLO is mostly given by the wider community which demonstrates the community's receptiveness and acceptance of its operations. Organisations do not only require regulatory authorisation to operate but also require social permission which represents the acceptance by key stakeholders and particularly the community within which the organisations operate. A youth representative explained:

The company has made many failed promises and because of their business interests, they want to change our perceptions about them. Many of their projects are public relations gimmicks.

A participant from Otunene village went as far as describing the presence of the oil companies in the area as 'a curse because there is no compensation to the community and no direct employment of the youth in the companies. Nothing tangible in any aspect'. A paramount ruler in Emeroke, one of the villages in Eastern Obolo, summarises the people's disappointment this way: 
The presence of oil companies in our community would have been a blessing no doubt if the memorandum of understanding between the community and the companies was followed. The presence of the companies was supposed to promote good commercial activities, bring social amenities, employment, empowerment, and so on. However, I see nothing since they have been operating in our area maybe because we don 't know our right.

A fisherman from Elekpon village said:

Their presence here is not a blessing but if my child after his education can work with any of the companies then it may be a blessing. For now, it is a curse. It is a curse because in the days of our forefathers, there used to be so many fishes in the river, but since the operation of these companies, the fishes have all disappeared making us experience hardship.

Participants also decried the way the oil companies had related with them. While each segment of the Eastern Obolo people had their own view of how the oil companies had related with them, the dominant view was that the relationship with the companies left much to be desired. For example, one of the participants, a fisherman, observed:

We don't have a good relationship with the oil companies especially those of us the fishermen. This is because the oil companies have not incorporated us the fishermen into any of their programmes, but they pretend to be socially responsible. Some of their projects are mere public relations gimmicks.

The Deputy Manager in charge of community relations of one of the oil companies was of the opinion that the company and the people of Eastern Obolo had a cordial relationship. He disclosed that before the company commenced operations in the area they discussed these with the representatives of the people and supported them to create the Community Relations Committee (CRC) to interface with the company. According to him,

The idea behind the formation of the CRC is to give feedback from community to company and vice versa. Again, it is to maintain a cordial relationship between the company and community. The CRC mediates between the community and company on all issues affecting the two parties.

However, the chairman of Eastern Obolo Community Relations Committee expressed mixed views regarding the relationship between communities and oil companies. The Deputy Community Relations Manager said:

The relationship with the companies had been cordial in terms of the company responding to phone calls and giving listening ears to complaints from the community. Frictions have always been because of the company's failure to keep to their promises. For me I think our company benefits as we have industrial peace if we initiate development projects. Projects bring our company closer to the people and the political decision-makers since we engage them in some of these issues.

The observation that the oil companies were giving listening ears to the community appeared to contradict the view of another respondent, a fisherman, who lamented that oil companies 'do 
not allow us fishermen to have access to them'. The explanation for these contradicting views could be that the oil companies related with each segment of the communities differently, perhaps based on socio-economic standing and capacity to mobilise the people against them. Overall, the respondents were unhappy regarding their relationship with the oil companies.

Obviously, the people generally expected more from the oil companies, believing that as the geese that laid the golden eggs, they deserved better than whatever they were currently getting from the companies. Their discontentment perhaps flows from the seeming inability of the companies to meet their expectations. This might explain why one of the respondents, an opinion leader in one of the villages in Eastern Obolo Council, noted that the oil companies were more of 'parasites' to the communities. This literally implied that these companies are creating more difficulties than the benefits they offer to the communities. A community representative explained:

They refuse to give our youth jobs. They refuse to give social amenities to the community. They fail to clean up oil spills. No embankment in the community to prevent coastal erosion. No empowerment but they keep on stealing from us.

Another community representative said that the oil companies 'are not doing well because the resources they are taking from the people are God-given. By virtue of this, the youth, women, chiefs, elders and students should be part of the benefits'. He believed that the current approach to CSR adopted by the oil companies was not helping the people as only few people benefit from it. To him,

The oil companies should construct good roads, provide water, build standard schools, build and equip hospitals, initiate good programs for the youth, women and elders. There should be training outfits within Eastern Obolo.

He called for an inclusive approach to CSR where the youths, the elderly, women and people with disabilities in the area would feel the presence of the oil companies positively. Another participant demanded modern fishing gear to be given to fishermen so that they can 'go into the deep sea to make reasonable catch'. Speaking for the youths, a youth leader in Isiotoyo, one of the communities in Eastern Obolo, lamented that the oil companies had been unfair to the majority of the youths, accusing them of giving opportunities to a handful of youths, especially those recommended by power brokers in the communities. He explained that a good working relationship with the youths would be mutually beneficial for both parties:

If they involved the youths, the possibility of engaging in crime would not be there. The oil companies should segment the people into youth, elders, chiefs and women so that every person can be carried along directly. Establishing the training outfit will help to reduce unemployment in the community. When greater percentages of the youth are engaged it will help to ameliorate the suffering of the people. The security aspect of the job of oil companies should be given to the youth, not strangers. By so doing, the youth will protect the oil facilities. But if given to strangers, they will connive with external bodies to vandalize the facilities while accusing fingers will be pointing at the youth.

Participants, however, did not rate all oil companies at the same level in terms of their CSR initiatives. While they accused all the oil companies of tokenism, they observed that some 
companies had done better than others. A participant from Agansa, one of the villages in Eastern Obolo Council, said:
A jetty has been constructed in my community by Amni and scholarship awarded to a few of our children in school by the same company. Other oil companies like Exxon Mobil, SPDC and Total E\&P have not done well with us.

The chairman of Eastern Obolo Community Relations Committee concurred that Amni was better than other companies in CSR.

In terms of infrastructure, Amni Petroleum International has performed more creditably than other oil companies like Shell Petroleum Development Company (SPDC), Exxon Mobil and Total E\&P that are also operating in our locality.

He said Amni had built science laboratories, libraries, and teachers' quarters in secondary schools in addition to sponsoring some youths to undergo training in skill acquisition centres. While agreeing that Amni and Total E \& P had done a couple of things for the people, he noted that there were still contentious issues:
I have been relating with Total E\&P, Amni Petroleum International, Exxon Mobil and Shell Petroleum Development Company (SPDC) whose facilities in the area have recently been acquired by Nigerian Petroleum Development Company (NPDC). Though Total E\&P and Amni Petroleum International have something to show in terms of development projects, the relationship with the community is not cordial. For Total E\&P, the memorandum of understanding (MOU) between the community and the company had not been completed and had expired. The community and Amni have been in court for over two years over the issue of a new community relations committee (CRC). The relationship between the community and Exxon Mobil is nothing to write home about despite operating within Eastern Obolo territory for decades.

From the responses of the participants, the people of Eastern Obolo would be satisfied if the oil companies operating in the area regularly awarded scholarships to students, supported their youths to acquire certain needed skills, employed people from the area at senior, middle and junior levels, and provided security as well as social amenities and infrastructure such as potable water, electricity, good road networks, jetties, and embankments, among others. There were also respondents who demanded that the companies relocate their headquarters to Eastern Obolo and pay tax to the council since their source of income was in the community. In terms of responses to environmental damage (like oil spills), there seemed to be a consensus amongst respondents that the oil companies had performed poorly. Participants observed that spills were either not cleaned up or best practices not followed if clean-up was done. For example, the chairman of Eastern Obolo Community Relations Committee observed that the

\section{oil companies ... continually damage the environment with no adequate care and compensation to the inhabitants.}

The chairman cited the case of an oil spill that occurred on October 2, 2016 which had not been cleaned up to date, but the position of the Deputy Manager, Community Relations, of one of the oil companies operating in Eastern Obolo appeared to contradict the views of other participants regarding compensation and clean-up of oil spills. The contradictory positions evident in this paper appear to suggest that there exists some level of distrust or expectation 
differentials between oil companies and the people of Eastern Obolo. The contradictory positions could not merely be a result of the fact that the evidence was drawn from different groups of participants but may demonstrate how the community has over the years interpreted oil companies' CSR actions. On the other hand, the contradictory positions may also simply highlight a difference of opinions of the efficacy of their CSR actions.

\section{Discussion and policy implications}

The results of our analysis present clear and consistent evidence that CSR is critical for the creation of cordial relationships between oil and gas companies and their host communities. Furthermore, oil and gas companies recognise that their continuous existence in local communities is endangered without the cooperation and support of local communities (Adonteng-Kissi \& Adonteng-Kissi, 2017). In view of this, the oil and gas companies operating in Eastern Obolo community may have to contribute to economic development of the local communities to strengthen cooperation and support of local communities. Over the years, several companies have been at the receiving end of protracted community agitation, since Obolo communities expect more social and economic infrastructure and employment. Though we share in the view that succeeding governments have failed in meeting the developmental/social needs of the people, the local communities tend to feel oil and gas companies attempt to secure SLO by engaging in CSR initiatives but not to genuinely improve their welfare. The assumption of SLO describes the social acceptability and level of acceptance of organisations' operations by key stakeholders, and especially local communities (Wilburn \& Wilburn, 2011). It is based on the notion that organisations need not only regulatory permission but also 'social acceptability' to conduct their operations. The SLO is embedded in the opinions, perceptions and beliefs held by local key stakeholders and communities about the operation of oil companies (Omotehinse \& De Tomi, 2020). This SLO is an implicit license aligned with the CSR activities of oil companies. Yet the evidence points to a superficial effort or incentive for oil and gas companies to engage in CSR initiatives in rural Africa. Participants in these communities noted that many of the oil companies failed to fulfil their promises. Owing to the difficulty in working in local communities and the attention that local communities have drawn in recent times, oil and gas companies are under strong public scrutiny, and are expected to support and develop rural communities where they operate (Auty, 2012; Ayentimi et al., 2016). The acceptance of corporate entities increasingly requires social license as an essential part of operating. Primarily, without satisfactory community support it is unlikely that public agencies will willingly grant operational licences or permits to support such operations (Wilburn \& Wilburn, 2011).

The discussion extends beyond the fact that oil and gas companies have a role to play in supporting rural development through social investment as well as investing in human capital and offering to provide the local population with the tools to drive their own economic development trajectory (Evans, 2018). The operations of oil and gas companies in Nigeria have been associated with local discontent and condemnation from both community members and civil society organisations across the sub-Saharan African region. Participants argued that owing to the extremely contentious character of the oil industry and the related risk of alienating their key stakeholders, oil and gas companies operating in the region superficially attempt to gain organisational and local legitimacy by undertaking CSR initiatives. However, the CSR projects have not mitigated the social and environmental costs of oil and gas development as most projects failed to address the priorities of communities. Many companies may have operated by securing SLO. The local communities can at best, from the viewpoint of Mitchell et al. 's (1997) concept of stakeholder salience be considered within the dimension of 
urgency of salience" (or maybe 'urgency salience' should remain as it is - if that's the way that Mitchell et al. phrase it, whereas power and legitimacy are more important in the theoretical hierarchy of salience (Donaldson \& Preston, 1995). This highlights the need for corporations to sustain all dimensions of the social contract to help in gaining both legal and social legitimacy. While the regulatory archetype of institutional legitimacy is underpinned by legal sanctions, the normative and cultural dimensions incorporate moral governance and expectations for community participation, accountability and transparency (Bond et al., 2018; Hummel \& Schlick, 2016). The advantage of CSR may be to bring companies closer to the people and political decision-makers, according to some participants of oil and gas companies. The evidence points to the notion that companies sometimes pretend to be socially responsible while in fact they may not be, as their actions and commitment towards the local communities' development have been limited. A critical drawback is that development priorities undertaken by oil and gas companies may be government representatives' or companies' initiatives and not essentially those of the local communities for whose welfare CSR initiatives are apparently pursued. This approach only tends to amplify the firm-community expectation differentials or mistrust in what may be genuine company-led CSR initiatives towards ameliorating the social and economic development of the communities.

The results of our analysis indicate that the social and environmental cost of oil development in the Eastern Obolo communities is easily noticeable and participants want these issues addressed since they affect their livelihoods and environment. The key pursuit that oil and gas companies must welcome, is finding the means of operation that do not destroy the environment or weaken the development prospects of local communities, while fairly distributing matching benefits among stakeholders and enhancing local economic growth (Ayentimi et al., 2016). Conversely, inadequate national macro-economic planning and management, supported by unfair distribution of resources, and an enabling environment, have substantial consequences for the general performance of CSR of oil and gas companies (Ite, 2004) contributing to the high level of mistrust between local communities and oil companies. In case of underperformance of the macro-economy owing to failure of government, perhaps the support of oil and gas companies towards ameliorating social problems might not be able to accomplish the desired results. This corroborates Ite's $(2004$, p.1) argument that 'good governance in all its dimensions is therefore an important component of the CSR agenda'. Oil and gas companies encounter challenges to enhance their performance in safeguarding the environment and local livelihoods and to protect the incorporation of sustainable development. They are expected to fulfil their corporate social and environmental responsibilities in reaction to growing pressure from the international community, employees, local communities and nongovernmental organisations (NGOs). The responsibility lies with oil and gas companies not to deliberately cause harm to local people (DesJardins \& Diedrich, 2003). When such destructions are caused to livelihoods and the environment, the onus lies on companies to compensate individuals who are impaired by their negligence or premeditated actions.

The Eastern Obolo communities are known for occasional clashes, under-development and environmental degradation even though the area hosts important oil and gas companies. Many failed promises have also been made by oil companies and state agencies. These issues have resulted in scepticism and mistrust on the part of the local population. The subject of 'trust' plays a critical role in the interaction between corporate organisations and local communities (Macaulay, 2018). Historically, the attitude of oil and gas firms regarding unfulfilled promises to Obolo communities has created negative perceptions and mistrust. Therefore, any CSR initiatives by oil companies do not always receive positive response in Eastern Obolo communities regardless of their laudability and impact. Companies may, nonetheless, achieve 
a wealth of gains in trust, including cost savings and improved organisational capacities (Wicks et al., 1999). The willingness of companies to generate reciprocally trusting relations is an issue of strategic choice. Thus, companies may, through their actions, assist in establishing degrees of trust in their interactions with stakeholders. Wicks, Berman and Jones (1999, p.99) contend that trust is 'an integral part of the strategy formulation process'. The circumstances for trust emerge when there is something that poses risk to one or more parties in a community (Wicks \& Berman, 2004). Trust offers an ethically convincing and economically effective means of tackling numerous difficulties arising out of cooperation when something poses risk to parties concerned. This discussion expresses the current circumstances and mistrust between oil and gas companies and local communities, suggesting that companies do not align CSR programs with the priorities of local communities. This situation suggests that CSR projects that are introduced to support community development without any alignment tend to bring short-term impact, while in the long term local communities may perceive such CSR initiatives as superficial.

Evidently, the results of our analysis point out several weaknesses in the CSR strategies and practices of oil companies in rural Africa. Oil companies can adopt more progressive initiatives that enhance diversity and inclusion, and those that offer continuous community engagement and community development (Adonteng-Kissi \& Adonteng-Kissi, 2018). Furthermore, the results of our analysis present clear and consistent evidence of development projects in support of many well-intentioned ideas but we did not see many partnerships where the company's involvement extended beyond development projects to include human resource development and capacity building. Some participants in Eastern Obolo communities consider some of the development projects as mere public relations gimmicks. In the short term, the CSR initiatives form decent public relations strategies. Oil companies may be required to compare short-term advantages of development projects which are intended as public relation gimmicks against the long-term enduring advantages of more complex, developmental projects that need profound participation from the local communities (Epstein, 2018; Cheng et al., 2014). Changing from a self-centred, narrow-minded approach to a durable, real developmental approach to their cross-segment collaborations would substantially improve the integrity regarding their CSR activities. This approach further points to the advancement of community engagement programs to find out priority areas for CSR alignment. Permitting potential beneficiaries to positively take part in development projects and identify with them is one of the appropriate approaches of community-embedded CSR initiatives (Block, 2018; Egbulonu \& Ojiako, 2018). Emphasis on community capacity-building promotes CSR strategies that provide durable, common social and commercial worth, rather than handling CSR as corporate legitimacy. CSR initiatives must be viewed as a legitimacy shared by local communities and oil companies. Disabling stakeholder scepticism and advancing the integrity of CSR communications are major difficulties in CSR initiatives for all companies and particularly for companies in contentious business domains (Du \& Viera Jr., 2012; Robinson \& Eilert, 2018; Beger, 2018).

It is an inevitable inference that CSR may potentially improve the relations between local communities and oil companies when the firm-community expectation differential (mistrust) is addressed. CSR projects need to deal with the sources of the community differences and distrust. Therefore, it is insufficient to make commitment to CSR objects or have CSR projects without aligning these to the sources of distrust. To some degree, CSR should provide a valuable avenue for lessening the adverse impacts of the available interactions among key stakeholders. Though some level of evidence shows that oil companies are making substantial attempts to fulfil their CSR commitments, yet such commitments alone are unable to adequately tackle the adverse impacts of oil and gas development. Furthermore, the 
fundamental matters engendering community indifference in most situations are usually generated by the absence of firm-community involvement or engagement during the formulation of their CSR initiatives. The unwillingness or the failure to incorporate community sensitivities into the formulation of CSR policies and permit positive community involvement in the execution of CSR projects further risks the legitimacy of CSR initiatives in the eyes of the community. An innovative approach needs to evolve where oil companies can virtually incorporate CSR with business competitive strategy by considering the needs and demands of stakeholders within the community. The absence of community legitimacy for oil and gas companies' CSR initiatives may potentially limit the constructive impact of CSR activities on local communities.

\section{Conclusion}

For CSR initiatives of oil and gas companies to address the expectation differentials, they must be implemented with attention to local communities' view of their legitimacy and their active involvement. This paper generates some managerial implications for oil and gas companies. Our study highlights the need to change from a mentality of CSR as a public relations gimmick to an enduring strategic approach built on a legitimacy shared by local communities and oil companies in the determination of CSR projects (Kim, Zapata \& Ramos, 2018; Lyon et al., 2018). Paradoxically, it is possible for oil and gas companies to focus on community-embedded CSR initiatives rather than focusing on securing SLO from their CSR engagement. Only through transparency and engagement with their major stakeholders to determine their exact needs, will oil and gas companies be able to design genuine and reliable CSR projects that, in the long term, change the local population's perceptions of the industry. CSR is a complicated issue for all corporate organisations and especially in contentious industries such as oil and gas (Du \& Viera Jr., 2012). Our paper provides valuable empirical evidence for designing CSR approaches and highlights the fact that building a community-driven CSR initiative requires a partnership in which local communities share legitimacy with oil companies in determining and influencing CSR initiatives. This will be the most effective way of enhancing corporate firm-community trust and social legitimacy in rural Africa. Finally, our paper broadly points to a balanced strategic approach to CSR and offers an analytic signal for reliable corporate firms' CSR engagement. At the governmental level, a proactive leadership role in influencing industry-level changes towards CSR in the oil and gas sector in Nigeria is required.

\section{References}

Ablo, A. D. 2018. Scale, local content and the challenges of Ghanaians employment in the oil and gas industry. Geoforum, 96 181-189.

Adonteng-Kissi, O. and Adonteng-Kissi, B. 2017. Living with conflicts in Ghana's Prestea mining area: is community engagement the answer? Journal of Sustainable Mining, 16, 196-206.

Adonteng-Kissi, O. and Adonteng-Kissi, B. 2018. Precarious work or sustainable livelihoods? Aligning Prestea's Programme with the development dialogue on artisanal and smallscale mining. Natural Resources Forum, 123-137.

Ako, R. T. 2007. Nigeria's land use act: An anti-thesis to environmental justice. Journal of African Law, 53(2), 289-304.

Auty, R. 2012. The oil curse: causes, consequences and policy implications. In R. E. Looney (Ed.), Handbook of Oil Politics (pp. 337-348). Routledge, London. 
Ayentimi, D. T., Burgess, J., and Brown, K. 2016. Developing effective local content regulations in sub-Sahara Africa: The need for more effective policy alignment. Multinational Business Review, 24(4), 354-374.

Barney, J. B., and Harrison, J. S. 2018. Stakeholder Theory at the Crossroads. Business \& Society, 1-10.

Beger, R. 2018. Present-Day Corporate Communication: A Practice-Oriented, State-of-theArt Guide (Springer).

Block, P. 2018. Community: The structure of belonging. Berrett-Koehler Publishers: Broadway, CA, US.

Bond, A., Pope, J., Retief, F., and Morrison-Saunders, A. 2018. On legitimacy in impact assessment: An epistemologically-based conceptualisation. Environmental Impact Assessment Review, 69, 16-23.

Cheng, B., , Ioannou, I., and Serafeim, G. 2014. Corporate social responsibility and access to finance. Strategic Management Journal, 35, 1-23.

Dal Maso, L., Mazzi, F., Soscia, M., and Terzani, S. 2018. The moderating role of stakeholder management and societal characteristics in the relationship between corporate environmental and financial performance. Journal of Environmental Management, 218, 322-332

de Gooyert, V., Rouwette, E., van Kranenburg, H., and Freeman, E. 2017. Reviewing the role of stakeholders in Operational Research: A stakeholder theory perspective. European Journal of Operational Research, 262, 402-410.

DesJardins, J. R., and Diedrich, E. 2003. Learning what it really costs: Teaching business ethics with life-cycle case studies. Journal of Business ethics, 48, 33-42.

Duff, A. 2017. Corporate social responsibility as a legitimacy maintenance strategy in the professional accountancy firm. The British Accounting Review, 49, 513-531.

Du, S. and Vieira Jr., E. T. 2012. Striving for Legitimacy Through Corporate Social Responsibility: Insights from Oil Companies. Journal of Business Ethics, 110, 413427.

Egbon, O., Idemudia, U., and Amaeshi, K. (2018). Shell Nigeria's Global Memorandum of Understanding and corporate-community accountability relations: A critical appraisal. Accounting, Auditing \& Accountability Journal, 31(1), 51-74.

Egbulonu, K. G., and Ojiako, E. U. 2018. Community Mobilization and Rural Development: A Case Study of Mbara Ozioma Foundation, Ehime Mbano, Imo State, Nigeria.

Epstein, M. J. 2018. Making sustainability work: Best practices in managing and measuring corporate social, environmental and economic impacts. Routledge: New York, US.

Evans, P. B. 2018. Dependent development: The alliance of multinational, state, and local capital in Brazil. Princeton University Press.

Fairclough, N. 2003. Analysing Discourse: Textual analysis for social research. Routledge: New York and London.

Farmaki, A., and Farmakis, P. 2018. A stakeholder approach to CSR in hotels. Annals of Tourism Research, 68, 58-60.

Fulmer, A., and Dirks, K. 2018. Multilevel trust: a theoretical and practical imperative. Journal of Trust Research, 8(2), 137-141.

Graham, P. 2003. Critical Discourse Analysis and Evaluative Meaning: Interdisciplinarity as a Critical Turn. In G. Weiss and R. Wodak (Eds), Critical Discourse Analysis Theory and Interdisciplinarity (pp.110-129). Palgrave Macmillan Ltd.

Guthrie, J., and Parker, L. D. 1989. Corporate Social Reporting: A Rebuttal of Legitimacy Theory. Accounting and Business Research, 19(76), 343-352. 
Haalboom, B. 2012. The intersection of corporate social responsibility guidelines and indigenous rights: Examining neoliberal governance of a proposed mining project in Suriname. Geoforum, 43 969-979.

Herrera-Racionero, P., Lizcano-Fernándezb, E., and Miret-Pastor, L. 2015. "Us" and "them”. Fishermen from Gandía and the loss of institutional legitimacy. Marine Policy, 54, 130136.

Hummel, K., and Schlick, C. 2016. The relationship between sustainability performance and sustainability disclosure -Reconciling voluntary disclosure theory and legitimacy theory. Journal of Accounting and Public Policy, 35, 455-476.

Hunoldt, M., Oertel, S., and Galander, A. 2018. Being Responsible:How Managers Aim to Implement Corporate Social Responsibility. Business \& Society, 1-42.

Ite, E. U. 2004. Multinationals and corporate social responsibility in developing countries: a case study of Nigeria. Corporate Social Responsibility and Environmental Management, 11, 1-11.

Jamali, D., \& Karam, C. 2018. Corporate Social Responsibility in Developing Countries as an Emerging Field of Study. International Journal of Management Reviews, 20, 32-61.

Kim, Y., \& Ramos, M. L. Z. 2018. Stakeholder responses toward fast food chains' CSR: Public health-related vs generic social issue-related CSR initiatives. Corporate Communications: An International Journal, 23, 117-38.

Korsgaard, M. A., Kautz, J., Bliese, P., Samson, K., and Kostyszyn, P. 2018. Conceptualising time as a level of analysis: New directions in the analysis of trust dynamics. Journal of Trust Research, 8(2), 142-165.

Lafreniere, K. C., Deshpande, S., Bjornlund, H. 2013. Extending stakeholder theory to promote resource management initiatives to key stakeholders: A case study of water transfers in Alberta, Canada. Journal of Environmental Management, 129, 81-91.

Lanis, R., \& Richardson, G. 2012. Corporate social responsibility and tax aggressiveness: a test of legitimacy theory. Accounting, Auditing \& Accountability Journal, 26(1), 75100.

Liao, P-C., Xia, N-N, Wu, C-L, Zhang, X-L., and Yeh, J-L. 2017. Communicating the corporate social responsibility (CSR) of international contractors: Content analysis of CSR reporting. Journal of Cleaner Production, 156, 327-336.

Liu, Y., Feng, T. and Li, S. 2015. Stakeholder Influences and Organization Responses: A Case Study of Corporate Social Responsibility Suspension. Management and Organization Review, 11:3, 469-491

Lumineau, F., and Schilke, O. 2018. Trust development across levels of analysis: An embedded-agency perspective. Journal of Trust Research, 8(2), 238-248.

Lyon, T. P., Delmas, M. A., Maxwell, J. W., Bansal, P., Chiroleu-Assouline, M., Crifo, P., Durand, R.., Gond, J-P., King, A., and Lenox, M. 2018. CSR Needs CPR: Corporate Sustainability and Politics. California Management Review: 0008125618778854.

Macaulay, S. 2018. Non-contractual relations in business: A preliminary study. in, The Law and Society Canon. Routledge: New York, US.

Ngoasong, M. Z. 2014. How international oil and gas companies respond to local content policies in petroleum-producing developing countries: a narrative enquiry. Energy Policy, 73, 471-479.

Nzeh, E., Famobuwa, O. S., and Iroechenwu, C. 2017. Land Reform System and Its Implications on Agricultural Production in Nigeria. Universal Journal of Agricultural Research, 5, 338 - 343.

Oke, B. R. 2006. How multinationals robbed Eastern Obolo. Ujama Magazine, pp. 10-11. 
Omotehinse, A. O., \& De Tomi, G. (2020). Managing the challenges of obtaining a social license to operate in the premining phase: A focus on the oil sands communities in Ondo State, Nigeria. World Development Perspectives, 18, 100200.

Onyishi, I. E., Amaeshi, K., Ugwu, F. O. and Enwereuzor, I. K. 2020. Going the Extra Mile Because My Organization Does: How Does Corporate Social Responsibility Influence Organizational Citizenship in Nigeria? Management and Organization Review, doi: 10.1017/mor.2019.44

Reinecke, J., Arnold, D. G. and Palazzo, G. 2016. Qualitative Methods in Business Ethics, Corporate Responsibility, and Sustainability Research. Business Ethics Quarterly, 26(4). doi: 10.1017/beq.2016.67

Robinson, S., and Eilert, M. 2018. The role of message specificity in corporate social responsibility communication. Journal of Business Research, 90, 260-68.

Sadler, D., and Lloyd, S. 2009. Neo-liberalising corporate social responsibility: A political economy of corporate citizenship. Geoforum, 40, 613-622.

Scott, W. R. 2001. Institutions and organizations (2nd ed.). Thousand Oaks, CA: Sage.

Susith, F., and Stewart, L. 2014. A theoretical framework for CSR practices: integrating legitimacy theory, stakeholder theory and institutional theory. The Journal of Theoretical Accounting, 10(1), 149-178.

Theodoulidis, B., Diaz, D., Crotto, F., and Rancati, E. 2017. Exploring corporate social responsibility and financial performance through stakeholder theory in the tourism industries. Tourism Management, 62, 173-188.

Thieme, T. A. 2015. Turning hustlers into entrepreneurs, and social needs into market demands: Corporate-community encounters in Nairobi, Kenya. Geoforum, 59 228-239

Tullberg, J. 2013. Stakeholder theory: Some revisionist suggestions. The Journal of SocioEconomics, 42, 127-135.

Wicks, A. C., and Berman, S. L. 2004. The effects of context on trust in firm-stakeholder relationships: the institutional environment, trust creation, and firm performance. Business Ethics Quarterly, 14, 141-60.

Wicks, A. C., Berman, S. L., and Jones, T. M. 1999. The structure of optimal trust: Moral and strategic implications. Academy of Management Review, 24, 99-116.

Xia, B., Olanipekun, A., Chen, Q., Xie, L., and Liu, Y. 2018. Conceptualising the state of the art of corporate social responsibility (CSR) in the construction industry and its nexus to sustainable development. Journal of Cleaner Production, 195, 340-353.

Xiao, C., Wang, Q., van Donk, D. P., and van der Vaart, T. 2018. When are stakeholder pressures effective? An extension of slack resources theory. International Journal of Production Economics, 199, 138-149. 